The Geneva Papers on Risk and Insurance, 16 (No. 60, July 1991), 315 - 326

\title{
Scale Economies and Performance in the French Insurance Industry
}

\author{
by F. Fecher, S. Perelman and P. Pestieau*
}

\begin{abstract}
The purpose of this paper is to provide for both life and non life insurance a measurement of economies of scale and an assessment of productive performance of French companies. We use a translog cost function to check the presence of scale economies and a parametric approach to construct our yardstick of productive efficiency. Our panel data covers 84 life and 243 non life companies for the period 1984-89. The main findings indicate both the existence of increasing returns to scale and a wide dispersion in the rates of inefficiency across companies. Those two results are shown to be closely linked to a number of characteristics of the companies studied, particularly their institutional form.
\end{abstract}

\section{Introduction}

As the completion of the internal market is getting close, a number of EEC member countries are rightfully concerned by the performance of their insurance industry. In the famous report on the "Cost of Non-Europe" I one finds quite striking price differentials for life and non-life insurance across eight EEC countries. Compared to the United-Kingdom, France is on average quite costlier for its various insurance products (even after controling for differences in taxes on insurance. Within the French market, one also finds discrepancies, though less dramatic, across companies. ${ }^{2}$ Many objections have been raiscd towards such results. We all know how much caution is nccded for a meaningful price comparison. It remains that such discrepancies cannot but call for some explanation pertaining to national regulation, scalc cconomics, market structurc and productive efficiency.

This paper addresses the issues of optimal scale and productive efficiency of the French insurance industry. We believe that the existence of scale economies and a wide dispersion of the productive cfficiency arc two factors contributing to relatively high prices. This could

"Department of Economics, University of Liège

Financial support from the Belgian Science Foundation ( $\left.F R F C n^{\circ} 2.4537 .90\right)$ and the Geneva Association are acknowledged. We wish to thank Denis Kessler for his suggestions and comments.

1 Emerson et al. (1988).

250 Millions de Consommateurs (1988. 1989). 
endanger the European future of the whole industry. Let us note however that this study is restrictcd to the Frcnch market; it should be conducted across European insurance companies to allow for efficiency and scale comparisons.

In this paper, we use premiums and claims as a proxy for size and output. To measure economies of scale, we estimate a cost function including besides premiums or claims various characteristics of the companies. To assess productive inefficiency which is a more general concept than that of partial productivity, we construct a production frontier, that is the maximum possible outputs which can be produced from given quantitics of a set of inputs. The indicator of productive inefficiency gives the distance between this frontier and the input-output vector of actual production in a given firm at a given period in timc.

Our estimations are based on a panel of 84 life and 243 non life companies for the pcriod 1984-89. The paper is organized as follows. Section 2 provides a quick introduction to the French insurance sector. Section 3 gives the estimates of the cost functions along with the cost elasticities for various scgmentations of the insurance industry. Section 4 presents the indicators of efficiency derived from the paramctric cstimation of production frontiers: various characteristics of the insurance companies are used to control for the wide dispersion in efficiency that we observe.

Before proceeding, we note that using either gross premium income or claims as a measure of scale and of output has been widely questioned. ${ }^{3}$ There is little doubt that these are not good proxies, but for the time being they are the best we have. This remark should just induce one to much caution when interpreting the forthcoming results.

\section{The insurance market in France}

In the EEC, the French insurance market ranks number three after Germany and the U.K. with a fifth of all premiums. Paradoxically, this market is both competitive and segmented. It is dominated by state-owned and mutual insurers, which comprise eight of the top ten groups (four state-owned and four mutuals). Mutuals takes about $60 \%$ of the motor insurance market. In the life insurance sector, the banks play a major role: over the last years, they have captured over half of the new business. This competitive climate has resulted in many acquisitions both at home and across borders. In 1989.23\% of the premiums written by French insurers came from other countries. As to segmentation, it can be perceived by looking at the wide dispersion across companies of characteristics such as the reinsurance ratios, the distribution ratios or the claim ratios. Mutuals in particular are known to cater to very particular groups of peoplc (school tcachcrs, clergymen...).

Table 1 and Table 2 give a description of the insurance market in France: they also provide the main data used in this study. ${ }^{4}$ First, we have gross premiums, claims and total costs. Then, four institutional typcs, the reinsurance ratio (proportion of reinsurance ceded to total gross premiums), and the distribution ratio (proportion of commissions paid to total costs incurred) are introduced as characteristics of insurance companies, which might have some cffect on their optimal scale and their level of performance.

\footnotetext{
3 See, e.g., O'Brien (1991), Hornstein and Prescott (1991), Hirshorn and Geehan (1977).

${ }^{4}$ From an original sample of 104 life insurance and 331 non life insurance companies, we have come down to 84 and 243 companies respectively, dropping observations which looked unreliable or which concern too small companies (gross premiums below 5 million FF).
} 
Table 1

Structure of non-life insurance in France

(Average values for 1984-89 in millions FF or in percent)

\begin{tabular}{|c|c|c|c|c|c|c|}
\hline $\begin{array}{l}\text { Firms } \\
\text { characteristics }\end{array}$ & $\begin{array}{l}\text { Firms } \\
\text { number }\end{array}$ & $\begin{array}{c}\text { Gross } \\
\text { premiums }\end{array}$ & Claims & $\begin{array}{l}\text { Total } \\
\text { cost }\end{array}$ & $\begin{array}{c}\text { Distribution } \\
\text { ratio } \\
(\%)\end{array}$ & $\begin{array}{c}\text { Reinsurance } \\
\text { ratio } \\
(\%)\end{array}$ \\
\hline \multicolumn{7}{|c|}{ Institutional form } \\
\hline Foreign & 78 & 112.9 & 60.9 & 47.1 & 74.7 & 34.8 \\
\hline Mutual & 86 & 737.3 & 517.3 & 220.1 & 39.7 & 36.9 \\
\hline Public & 4 & $11,949.8$ & $8,148.9$ & $4,092.9$ & 54.3 & 15.9 \\
\hline Stock & 75 & 863.5 & 486.2 & 333.5 & 54.0 & 36.5 \\
\hline Total & 243 & 760.4 & 486.8 & 263.3 & 55.6 & 35.8 \\
\hline \multicolumn{7}{|l|}{$\underline{\text { Scale }}^{*}$} \\
\hline $5-30$ & 55 & 15.5 & 7.5 & 6.2 & 68.7 & 37.5 \\
\hline $30-150$ & 80 & 80.7 & 35.1 & 35.2 & 56.2 & 41.6 \\
\hline $150-400$ & 44 & 258.3 & 130.3 & 95.5 & 47.1 & 38.9 \\
\hline $400-$ & 64 & $2,596.4$ & $1,701.4$ & 885.0 & 49.1 & 25.0 \\
\hline Total & 243 & 760.4 & 486.8 & 263.3 & 55.6 & 35.8 \\
\hline
\end{tabular}

Table 2

Structure of life insurance in France

(Average values for 1984-89 in millions FF or in percent)

\begin{tabular}{|c|c|c|c|c|c|c|}
\hline $\begin{array}{l}\text { Firms } \\
\text { characteristics }\end{array}$ & $\begin{array}{l}\text { Firms } \\
\text { number }\end{array}$ & $\begin{array}{c}\text { Gross } \\
\text { premiums }\end{array}$ & Claims & $\begin{array}{l}\text { Total } \\
\text { cost }\end{array}$ & $\begin{array}{c}\text { Distribution } \\
\text { ratio } \\
(\%)\end{array}$ & $\begin{array}{c}\text { Reinsurance } \\
\text { ratio } \\
(\%)\end{array}$ \\
\hline \multicolumn{7}{|c|}{$\underline{\text { Institutional form }}$} \\
\hline Foreign & 15 & 224.8 & 132.5 & 76.8 & 25.3 & 7.4 \\
\hline Mutual & 13 & 989.9 & 437.4 & 156.5 & 28.3 & 16.3 \\
\hline Public & 4 & $8,628.9$ & $6,263.1$ & $1,508.9$ & 25.2 & 4.7 \\
\hline Stock & 52 & 929.0 & 303.3 & 135.8 & 34.6 & 9.1 \\
\hline Total & 84 & $1,180.7$ & 577.3 & 193.9 & 31.4 & 9.7 \\
\hline \multicolumn{7}{|l|}{$\underline{\text { Scale }}^{*}$} \\
\hline $5-100$ & 23 & 35.7 & 13.3 & 12.5 & 29.6 & 12.0 \\
\hline $100-300$ & 16 & 178.4 & 73.1 & 70.4 & 34.3 & 17.1 \\
\hline $300-1000$ & 20 & 573.4 & 236.4 & 111.9 & 29.4 & 4.1 \\
\hline $1000-$ & 25 & $3,361.6$ & $1,691.6$ & 505.3 & 32.8 & 7.2 \\
\hline Total & 84 & $1,180.8$ & 577.3 & 193.9 & 31.4 & 9.7 \\
\hline
\end{tabular}

* measured by gross premium income in millions FF. 
Public companies in either property-liability of life insurance have on average al disproportionate size relatively to the stock, mutual and foreign companies. Not surprisingly the distribution ratio is the lowest for mutual non-life companies and is higher in non-life than in life companies. The reinsurance rate decreases with the scale and it is particularly low in public companics.

\section{Scale economies}

There exists a small number of studies on economies of scale in French insurance companies. Rosa (1974) was the first to estimate the relationship of premiums to expenses in non life insurance. He concluded that increasing returns to scale exist and attributes them to the rapid growth of the insurance sector in the early seventics. Guimiot (1977) studied life insurance and looked at the relationship of unit costs to either premiums or insured amounts for the years 1971-1973. He didn't find any economies of scale. Outreville (1987) updated those studies for 1981 - 1982. In life insurance, he used premiums as a proxy for size and in non life, he used either premiums or claims. He consistently obtained increasing returns to scale. Dubois (1988) tested a number of models for non life insurance and concluded to the absence of cconomies of scale. Finally, Lahaye et al. (1990) in a study close to

Table 3

Cost function estimators ${ }^{*}$

Non life insurance

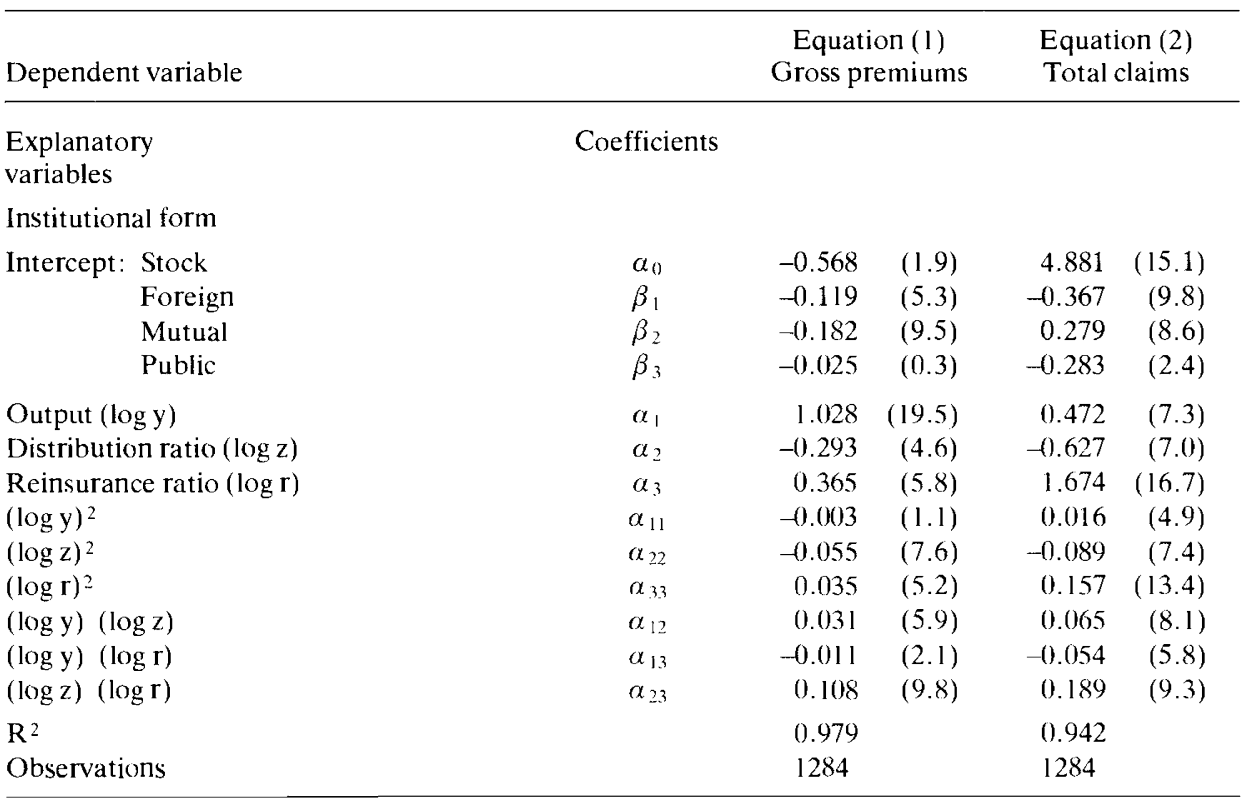

*t-tests are given into brackets. 
the present one but for the period 1982-1987, found increasing returns to scale in both life and non life insurance with some variability according to a few characteristics of the companies studied.

We have chosen one of the most traditional and general cost functions used in the literature, namely the translog function which can be written as:

$$
\begin{aligned}
\log c_{s t}= & \alpha_{t}+\alpha_{1} \log y_{s t}+\alpha_{2} \log z_{s t}+\alpha_{3} \log r_{s t}+\alpha_{11}\left(\log y_{s t}\right)^{2}+\alpha_{22}\left(\log z_{s t}\right)^{2}+ \\
& \alpha_{33}\left(\log r_{s t}\right)^{2}+\alpha_{t 2}\left(\log y_{s t}\right)\left(\log z_{s t}\right)+\alpha_{13}\left(\log y_{s t}\right)\left(\log r_{s t}\right)+ \\
& \alpha_{23}\left(\log r_{s t}\right)\left(\log z_{s t}\right)+\Sigma \beta_{j} s_{j}+\varepsilon_{s t}
\end{aligned}
$$

where $c_{s t}$ denotes total costs of the $s$-th company in year $t, y_{s t}$, the output variable (gross premiums or claims), $z_{s t}$, the distribution ratio and $r_{s t}$, the reinsurance ratio. The Greek letters $\alpha$ and $\beta$ are the regression coefficients, the $s_{j}$ 's are the binary variables attached to the institutional form with the exception of stock companies to which the constant $\alpha_{\theta}$ applies. The last term $\varepsilon_{s t}$ is the random term. ${ }^{5}$

We start with the non life insurance companies; equation (1) was estimated with OLS. The coefficients are given in Table 3 . Most of them are very significant, in particular when claims are used as the output measure. The impact of the institutional form on costs is mixed. Foreign and public companies seem to be less costly than mutuals and stock companies. In view of important cross effects, one has to compute the total cost elasticities to check the effect of scale (proxied by either gross premiums or claims), reinsurance and distribution. These elasticities are presented on Table 4.

\section{Table 4}

\begin{tabular}{|c|c|c|c|c|c|c|}
\hline \multirow[b]{2}{*}{$\begin{array}{l}\text { Firms } \\
\text { characteristics }\end{array}$} & \multicolumn{3}{|c|}{ Equation (1) } & \multicolumn{3}{|c|}{ Equation (2) } \\
\hline & $\begin{array}{c}\text { w. r. t. } \\
\text { gross } \\
\text { premiums }\end{array}$ & $\begin{array}{l}\text { w. r. t. } \\
\text { distribution } \\
\text { ratio }\end{array}$ & $\begin{array}{l}\text { w. r.t. } \\
\text { reinsurance } \\
\text { ratio }\end{array}$ & $\begin{array}{l}\text { w. r.t. } \\
\text { claims }\end{array}$ & $\begin{array}{l}\text { w. r. t. } \\
\text { distribution } \\
\text { ratio }\end{array}$ & $\begin{array}{l}\text { w. r. t. } \\
\text { reinsurance } \\
\text { ratio }\end{array}$ \\
\hline \multicolumn{7}{|c|}{ Institutional form } \\
\hline Foreign & 0.979 & -0.077 & 0.118 & 0.845 & -0.198 & 0.640 \\
\hline Mutual & 0.940 & 0.087 & 0.005 & 0.819 & 0.081 & 0.419 \\
\hline Public & 0.945 & 0.091 & 0.005 & 1.046 & 0.178 & 0.150 \\
\hline Stock & 0.956 & 0.041 & 0.070 & 0.872 & 0.013 & 0.524 \\
\hline Total & 0.957 & 0.023 & 0.060 & 0.847 & -0.023 & 0.514 \\
\hline
\end{tabular}

Cost elasticities in non life insurance Average values by institutional form

w. r. t.: with respect to

${ }^{5}$ We have not introduced here a time variable. In previous tests, it didn't appear significant which is consistent with the findings of Baumol (1991) and Wolff (1991) for whom in the U.S. there is hardly any technical progress in the insurance industry. 
Overall one notes some increasing returns to scale (that is elasticities below 1). There are few differences between institutional forms. There is just one cxception which concerns the four public companies; this is not surprising given their sizc. The cost elasticities with respect to the distribution ratio are positive for all types of companies but the foreign oncs. The cost elasticities with respect to reinsurance are everywhere positive; they are much lower with premiums than with claims. It is also particularly low for public companics, which are known to have both low reinsurance ratios and large scale.

Turning now to life insurance companies, the OLS regression estimators are given in Table 5. The coefficicnts are lcss significant than thosc obtained for non life insurance. We present the cost elasticitics in Table 6. Again, we notice overall the existence of cconomies of scale. This holds for all companies but the public ones. The distribution ratio has a negative effect on costs overall and in most of the cascs studied. In that respect, one has to keep in mind that the distribution ratio and the role of banks in life insurance are inversely related. For obvious rcasons, costs tend to be lower in companies linked to bank networks. Finally, the cost elasticities with respect to the reinsurancc ratio is consistently positive; this finding agrees with the hypothesis that less efficient firms tend to seek reinsurance; we shall come back to this in the next section.

Table 5

Cost function estimators*

Life insurance

\begin{tabular}{|c|c|c|c|c|c|}
\hline Dependent variable & \multirow[b]{2}{*}{ Coefficients } & \multicolumn{2}{|c|}{$\begin{array}{l}\text { Equation (1) } \\
\text { Gross premiums }\end{array}$} & \multicolumn{2}{|c|}{$\begin{array}{l}\text { Equation (2) } \\
\text { Total claims }\end{array}$} \\
\hline $\begin{array}{l}\text { Explanatory } \\
\text { variables }\end{array}$ & & & & & \\
\hline \multicolumn{6}{|l|}{ Institutional form } \\
\hline $\begin{aligned} \text { Intercept: } & \text { Stock } \\
& \text { Foreign } \\
& \text { Mutual } \\
& \text { Public }\end{aligned}$ & $\begin{array}{l}\alpha_{0} \\
\beta_{1} \\
\beta_{2} \\
\beta_{3}\end{array}$ & $\begin{array}{r}2.681 \\
0.431 \\
-0.101 \\
0.196\end{array}$ & $\begin{array}{l}(1.6) \\
(4.9) \\
(1.1) \\
(0.9)\end{array}$ & $\begin{array}{r}8.446 \\
0.128 \\
-0.012 \\
-0.295\end{array}$ & $\begin{array}{r}(12.9) \\
(1.6) \\
(0.2) \\
(1.7)\end{array}$ \\
\hline Output $(\log y)$ & $\alpha_{1}$ & 0.486 & (1.7) & -0.046 & $(0.4)$ \\
\hline Distribution ratio $(\log z)$ & $\alpha_{2}$ & -0.233 & $(0.9)$ & 1.017 & (6.8) \\
\hline Reinsurance ratio $(\log r)$ & $\alpha_{3}$ & -0.214 & $(1.0)$ & -0.084 & $(0.5)$ \\
\hline$(\log y)^{2}$ & $\alpha_{11}$ & 0.018 & (1.6) & 0.036 & $(6.2)$ \\
\hline$(\log z)^{2}$ & $\alpha_{22}$ & -0.120 & (4.4) & 0.126 & (5.4) \\
\hline$(\log r)^{2}$ & $\alpha_{33}$ & -0.066 & $(2.8)$ & -0.139 & $(6.0)$ \\
\hline$(\log y)(\log z)$ & $\alpha_{12}$ & -0.002 & $(0.1)$ & 0.007 & $(0.5)$ \\
\hline$(\log y)(\log r)$ & $\alpha_{13}$ & 0.029 & (1.7) & 0.007 & $(0.7)$ \\
\hline$(\log z)(\log r)$ & $\alpha_{23}$ & 0.091 & $(2.4)$ & 0.146 & $(4.8)$ \\
\hline $\mathrm{R}^{2}$ & & 0.863 & & 0.887 & \\
\hline Observations & & 430 & & 428 & \\
\hline
\end{tabular}

${ }^{*}$ t-tests are given into brackets. 
Table 6

Cost elasticities in life insurance

Average values by institutional form

\begin{tabular}{|c|c|c|c|c|c|c|}
\hline \multirow[b]{2}{*}{$\begin{array}{l}\text { Firms } \\
\text { characteristics }\end{array}$} & \multicolumn{3}{|c|}{ Equation (1) } & \multicolumn{3}{|c|}{ Equation (2) } \\
\hline & $\begin{array}{c}\text { w. r. t. } \\
\text { gross } \\
\text { premiums }\end{array}$ & $\begin{array}{l}\text { w. r. t. } \\
\text { distribution } \\
\text { ratio }\end{array}$ & $\begin{array}{l}\mathrm{w}, \mathrm{r}, \mathrm{t} . \\
\text { reinsurance } \\
\text { ratio }\end{array}$ & $\begin{array}{l}\text { w. r.t. } \\
\text { claims }\end{array}$ & $\begin{array}{l}\text { w. r. t. } \\
\text { distribution } \\
\text { ratio }\end{array}$ & $\begin{array}{l}\mathrm{w} . \mathrm{r}, \mathrm{t} \text {. } \\
\text { reinsurance } \\
\text { ratio }\end{array}$ \\
\hline \multicolumn{7}{|c|}{ Institutional form } \\
\hline$\overline{\text { Foreign }}$ & 0.812 & -0.170 & 0.348 & 0.692 & -0.008 & 0.194 \\
\hline Mutual & 0.857 & -0.024 & 0.334 & 0.740 & 0.169 & 0.094 \\
\hline Public & 0.957 & -0.184 & 0.516 & 1.031 & 0.007 & 0.112 \\
\hline Stock & 0.843 & -0.215 & 0.433 & 0.724 & -0.064 & 0.116 \\
\hline Total & 0.845 & -0.174 & 0.405 & 0.736 & -0.012 & 0.127 \\
\hline
\end{tabular}

w. r. t.: with respect to

\section{Firm-specific productive efficiency ${ }^{6}$}

On the basis of that same panel data, we now analyze the productive efficiency of non life insurance on the basis of a stochastic production frontier that we represent by the following Cobb-Douglas function:

$$
\log y_{s t}=\lambda_{\theta}+\lambda_{1} \log x_{I s t}+\lambda_{2} \log x_{2 s t}+\omega_{s t}
$$

where $\gamma_{s t}$ represents the output of the $s$-th company in year $t, x_{i s t}(i=1,2)$ denotes input $i$, $\lambda_{0}, \lambda_{1}$ and $\lambda_{2}$ are parameters to be estimated. The term $\omega_{s t}$ is a composed error term such that $\omega_{s t}=v_{s t}-\mu_{s}$, with $v_{s t}$, a symmetric normal term capturing randomness outside of the control of the firm and $\mu_{s}(\geq 0)$, a one-sided component, independent of $v_{s t}$, capturing randomness assumedly under the control of the firm. This latter term is used to derive the indicator of technical efficiency. Within this approach we use gross premiums as our output variable. The two inputs are labor costs including commissions taken as a proxy for the labor input and all the other expenses taken as a proxy for intermediate inputs.

In order to estimate technical efficiency we choose the maximum likelihood procedure proposed by Battese and Coelli (1988). Specially designed to deal with panel data, this procedure amounts to estimating the conditional expectations of the individual efficiencies $\mu_{s}$ assumed to follow a normal distribution, $N\left(m, \sigma^{2}\right)$, with truncation at zero. Compared with the traditional half-normal distributional hypothesis this maximum likelihood procedure? allows for a more flexible modelisation of inefficiencies, including the half-normal distribution as a special case corresponding to $m=0$. Table 7 and 8 present the main results for life and non life companies, respectively. The corresponding estimators are reported in the Appendix.

\footnotetext{
${ }^{n}$ This section is heavily based on Fecher et al. (1991).

7 To estimate this model we use the econometric package FRONTIER written by Coelli (1989) and specially conceived to deal with unbalanced panel data.
} 
Overall the average level of efficiency is very low and the dispersion very high. This variability can be explained in part by the nature of the data. They come from the annual accounts of individual insurance companies which often provide questionable figures. It is also due to the volatility of the insurance markets. In our sample, there are a number of companies which either started or disappeared during the short period 1984-1989. ${ }^{8}$ This variability is also due to the high segmentation of the insurance market in France.

We shall try to see whether some characteristics of non life insurance companies can account for differences in efficiency. Table 7 shows how those these efficiency measures vary with the institutional type, the reinsurance ratio, the scale proxied by gross premiums, the claims to premiums ratio, and the distribution ratio of companies. Efficiency is higher in public companies than in the three other institutional types of companies. Efficiency increases with size and this is not just due to the large size public companies. Efficiency seems to

\section{Table 7}

Efficiency measure and firms' characteristics in non-life insurance

\begin{tabular}{cccc}
\hline Characteristics & Number & Range & Efficiency measure \\
\hline Institutional form & & & \\
Foreign & 78 & & 0.493 \\
Mutual & 86 & & 0.477 \\
Public & 4 & & 0.374 \\
Stock & 75 & & 0.386 \\
Distribution ratio & 86 & $0-50$ & 0.373 \\
(\%) & 102 & $50-75$ & 0.382 \\
Reinsurance auto & 105 & $75-100$ & 0.466 \\
(\%) & 85 & $0-20$ & 0.404 \\
Scale (millions FF) & 86 & $20-50$ & 0.359 \\
& 72 & $50-100$ & 0.347 \\
Claims to Premium ratio & 55 & $5-30$ & 0.351 \\
$\quad \%)$ & 80 & $30-150$ & 0.465 \\
& 44 & $150-400$ & 0.509 \\
Total & 64 & $400-$ & 0.337 \\
Standard deviation & 58 & $1-30$ & 0.381 \\
Range & 72 & $30-50$ & 0.449 \\
\hline
\end{tabular}

${ }^{8}$ We have a balanced panel for 48 life and for 164 non-life companies. 


\section{Table 8}

Efficiency measure and firms' characteristics in life insurance

\begin{tabular}{cccc}
\hline Charactcristics & Number & Range & Efficiency measure \\
\hline Institutional form & & & \\
Foreign & 15 & & 0.076 \\
Mutual & 13 & & 0.250 \\
Public & 4 & & 0.183 \\
Stock & 52 & & 0.293 \\
Distribution ratio & 23 & $0-20$ & 0.260 \\
(\%) & 34 & $20-40$ & 0.181 \\
Reinsurance auto & 27 & $40-100$ & 0.304 \\
(\%) & 17 & $0-1$ & 0.507 \\
& 29 & $1-5$ & 0.246 \\
Scale (millions FF) & 25 & $5-20$ & 0.135 \\
& 15 & $20-100$ & 0.095 \\
& 23 & $5-100$ & 0.117 \\
Claims to Premium ratio & 16 & $100-300$ & 0.144 \\
(\%) & 20 & $300-1000$ & 0.320 \\
& 25 & $1000-$ & 0.359 \\
Total & 23 & $0-20$ & 0.426 \\
Standard deviation & 18 & $20-40$ & 0.265 \\
Range & 18 & $40-60$ & 0.131 \\
& 25 & $60-100$ & 0.138 \\
\hline
\end{tabular}

decrease with the distribution ratio. Reinsurance seems to have a depressive impact on efficiency whereas the claims ratio ${ }^{9}$ has on the contrary a positive effect. The latter result is not surprising. One must realize that in a steady-state world, the difference between premiums and claims should just include costs and profits, which both are minimized in a competitive setting.

We shall proceed with life insurance companies in the same way as with the non life insurance companies. The efficiency measures so derived are presented in Table 8 in terms of overall average values, average values per institutional type and other characteristies. Again, average efficiency is quite low, lower indeed that for non life. The dispersion of estimates is large with companies ranging from almost complete incfficiency to full cfficiency.

\footnotetext{
${ }^{9}$ That is, the ratio of incurred losses to earned premiums.
} 
With regard to the institutional form, public life insurance companies are no longer the most efficient. In fact, mutual and stock companies perform better than public ones. In Table 8 , we can also see the effects on efficicncy of other characteristics of life insurance companies. We find the following pattern: (i) efficiency increases with scale; (ii) it decreases with the reinsurance ratio and with the claims ratio: (iii) it first decreases and then increases as the distribution ratio increases. The effect of scale is the same as in non-life insurance. This is an interesting result particularly if we note that productive scale effects are already taken into account in constructing the efficiency frontier. The effect of the claims ratio is totally different from that observed in non life insurance. In fact, this ratio rcflects two opposite characteristics: the pressure on costs and on profits as observed before and the maturity of the company. The latter characteristic is particularly important in life insurance where the time gap between paying premiums and getting benefits can be long. In this particular instance, this is the dominant characteristic. Young companies which cash in premiums while hardly paying any claims are unexpectedly "more efficient". To put it another way, if we use claims as a measure of the output, that effect would disappear. Efficiency decreasing with reinsurance might pertain to issues of self-responsibility and incentives. These factors can also explain the ambiguous relation between efficiency and the distribution ratio.

In Figure 1, we compare the distribution of productive efficiency indicators for the two types of insurance. One clearly sees their wide dispersion and the differences between life and non life sectors.

Figure 1

Frequency distribution of firm-specific efficiency measures in life and non life insurance

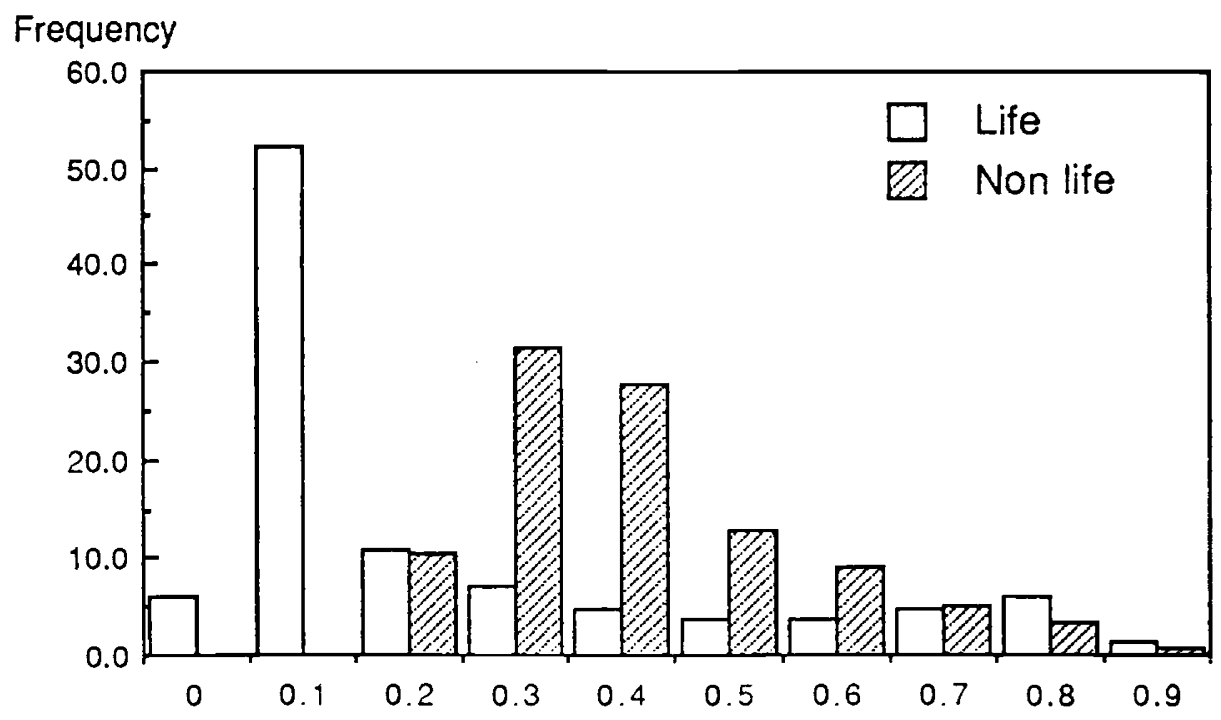




\section{Conclusions}

In this paper, we have attempted to measure two factors which might contribute to endangering the French insurance industry in the increasingly competitive European setting, namely, the presence of scale economies and the existence of productive inefficiencies. We have found that most companies don't have an optimal size, though to a lesser extent for the public ones. Second, in both life and non life insurance, there is a wide dispersion of efficiency, the average efficiency being about $40 \%$ for non life and $25 \%$ for life insurance; however, a sizeable part of that dispersion can be accounted for by the huge segmention of the French insurance market. Indeed, efficiency seems to depend on various characteristics of insurance companies.

In view of the problems related to measuring size and outputs of insurance companies, those conclusions are to be taken as indicative and not firm. The combined introduction of better concepts for the outputs of insurance and better data on output functions seems to be the only way for obtaining more reliable findings.

In any case, such study is only one step towards a true comparative study of efficiency and economies of scale of the European insurance industry. The next step will be to apply the same tests to other countries and then to proceed with comparisons.

\section{APPENDIX}

Estimation of Cobb-Douglas stochastic production frontiers for non life and life insurancel

\begin{tabular}{lcccccc}
\hline $\begin{array}{l}\text { Variables } \\
\text { Parameters }\end{array}$ & Intercept & Labor & $\begin{array}{c}\text { Composite } \\
\text { input } \\
\lambda_{2}\end{array}$ & $\sigma^{2}(v+\mu)$ & $\gamma^{(2)}$ & $m$ \\
\hline & $\lambda_{0}$ & $\lambda_{1}$ & & & & \\
Dependent Variables & & & & & & \\
$\begin{array}{l}\text { Non life gross } \\
\text { premiums }\end{array}$ & 0.32 & 0.72 & 0.20 & 0.153 & 0.927 & 0.981 \\
$\begin{array}{l}\text { Life gross } \\
\text { premiums }\end{array}$ & $(43.9)$ & $(55.6)$ & $(16.7)$ & $(10.0)$ & $(162.5)$ & $(16.5)$ \\
& $(17.1)$ & $(13.9)$ & $(16.4)$ & $(8.2)$ & $(330.7)$ & $(10.9)$
\end{tabular}

1) $\mathrm{t}$-tests are given into brackets.

2) $\gamma=\left(\sigma_{\mu}\right)^{2} /\left(\sigma_{v+\mu}\right)^{2}$. 


\section{REFERENCES}

Assurances automobile-habitation. (1989). 50 Millions de Consommateurs. $\mathrm{n}^{\circ} 40$.

BATTESE. G. E. and COELLI. T. J.. (1988). Prediction of firm-level technical efficiencies with a generalized frontier production function and panel data. Journal of Econometrics. 38. 387-399.

BAUMOL. W.. (1991). Technological imperatives. productivity and insurance costs. The Geneva Papers, 59, 154-165.

Bien choisir votre assurance: vie-décès-retraite. (1988). 50 Millions de Consommateurs. no 34.

COELLI. T. J.. (1989). Estimation of frontier production functions: a guide to the computer progran "Frontier". Working paper \# 34. Department of Econometrics. University of New England.

DUBOIS. P.. (1988). Estimation d une fonction de coût hédonique. mimeo. University of Caen.

EMERSON. M. et al.. (1988). The economics of 1992, European Economy, n" 35.

FECHER. F. KESSLER. D.. PERELMAN. S. and PESTIEAU. P.. (1990). Productive performance and the French insurance industry. mimeo. Université de Liège.

GUIMIOT. J. C.. (1977). Assurance-vie et rendements de dimension. in J. J. Rosa (ed.). Economie des Intermédiaires Financiers. Paris. Economica. 134-147.

HIRSHORN, R. and GEEHAN. G., (1977). Measuring the real output of the life insurance industry. Review of Economics and Statistics. 59.211-219.

HORNSTEIN. A. and PRESCOTT. E. C.. (1991). Measure of the insurance sector input. The Geneva Papers. 59. 191-206.

LAHAYE. J. M. . PERELMAN. S. and PESTIEAU. P.. (1990). Les économies de dimension dans l'assurance française. Revue d'Economie Financière. 11. pp. 105-111.

O BRIEN. C. D.. (1991). Measuring the output of life insurance companies. The Geneva Papers. 59. 207-235.

OUTREVILLE. J. F.. (1987). Lassurance en France: essais d analyses macroéconomiques. Etudes et Dossiers. 113. Association de Genève.

ROSA. J. J.. (1974). Les économies de dimension des institutions financières. Revue de la Banque. 309. $491-497$.

WOLFF, E. (1991). Productivity growth. capital intensity. and skill levels in the U.S. insurance industry. 1948-86: a preliminary look. The Geneva Papers. 59. 173-190. 